\title{
The Use of Serious Games in the Education of Engineers
}

\author{
Jannicke Madeleine Baalsrud Hauge ${ }^{1}$, Borzoo Pourabdollahian ${ }^{2}$, \\ and Johann C.K.H. Riedel ${ }^{3}$ \\ ${ }^{1}$ Bremer Institut für Produktion und Logistik, Bremen, Germany \\ baa@biba . uni-bremen. de \\ ${ }^{2}$ Politecnico di Milano, Milan, Italy \\ borzoo.pourabdollahian@mail.polimi.it \\ ${ }^{3}$ Nottingham University Business School, Nottingham, UK \\ johann.riedel@nottingham.ac.uk
}

\begin{abstract}
Serious games have been used in the education of engineering students and professionals for decades, but still they have not reached their maximum diffusion. Learning by gaming is often seen as not serious enough within higher education and vocational training. Consequently, gaming as a teaching method is still often excluded from many curricula. Hence, students lack the experience of active knowledge acquisition during lessons and encounter a barrier for successful participation in serious games later. Although a variety of games have been developed and proved successful for the mediation of skills in complex systems (Windhoff, 2001), this paper discusses why we think that serious games should be considered as a suitable learning method for the mediation of skills needed in the education of engineers and secondly to give some examples of current games and experience of their use.
\end{abstract}

Keywords: Serious Games, Engineering Education.

\section{Introduction}

Today manufacturing is often a complex process, involving several partners around the world. The products are more customized and have shorter life-cycle times, which increases the marginal cost per product. As the employee is the person in an organisation that performs and lives collaboration, the organisational success will mainly depend on his/her capabilities to learn and act in a dynamic environment (Windhoff, 2001). Decision makers, like people in general, are prone to the misperceptions of feedback. This means that their performance in complex and dynamic systems is hindered by non-linearity, time delays and feedback structures (Sterman, 1989). Decision making in dynamic systems is hard because it calls for dynamic decision making, which is a stream of decisions closely depending on one another. Thus, the question is: which skills does an employee need in order to perform well in collaborations, and how is it possible to mediate skills in such a way that he/she can act as needed when a new situation arises and how can engineering students be prepared for this during their studies?

Manufacturing and engineering education needs to focus on developing the skills required by new generations of employees; adapting the educational content and its 
delivery mechanisms to the new requirements of knowledge-based manufacturing, the provision of integrated engineering competencies, including a variety of soft skills, and the promotion of innovation and entrepreneurship (Taisch, 2011, p.11). In order to achieve this, it is necessary to focus more on multi-disciplinarity and integrated engineering competencies (Taisch, 2011).

\section{Why Use Serious Games}

The term Serious Games mainly refers to games that are primarily designed for nonentertainment purposes. According to Corti (2006) a Serious Game "is all about leveraging the power of computer games to captivate and engage end-users for a specific purpose, such as to develop new knowledge and skills". This unique feature significantly supports new requirements in engineering education; especially those that cannot be taught by traditional means. For example, students can interact in virtual environments, which will confront them with complicated situations in which they need to gather and analyse information to take critical decisions. To reach this goal they are pushed to improve their soft skills, such as communication and negotiation, as well as technical skills. Experience so far with the use of serious games in the education of engineers has shown a positive effect on the students' abilities both, to apply the theoretically gained knowledge and to enhance required business skills for a qualified engineer.

Learning by serious games can be clarified by Kolb's experiential learning cycle, which views learning as a process, which includes four essential phases: Active experimentation and specific experience, Direct experience, Reflexion, and Assesment. Active experimentation and testing lead to direct experience (Straka, 1986). Direct experience allows for reflection on different aspects of the experienced situation both at an individual as well as at a group level. Based upon this reflection, an assessment as well as a definition of the consequences and potential generalization possibilities leads to the awareness of new actions. This experiential learning approach requires a free, self directed and self organized learning process. Effective engineering education needs a learning-by-doing approach characterised by moving from passive perception to active experience. However, there are not enough real life situations that can be used for education or training, since in many real life situations the occurrence of errors or mistakes - which are natural in learning situations - are not acceptable. Simulation games using advanced information and communication technology can be used as a substitute in order to meet this need for active experience (Riis, 1995; Radcliffe \& Teakle, 1994).

Creating knowledge by gaming has proved to be particularly effective whenever soft skills are essential and traditional learning methods fail (Windhoff, 2001). Warren and Langley (1999) underscored that decision makers should have access to gaming simulation tools in order for them to cope with the business systems in which they evolve, and to reap strategic management skills. Scholz-Reiter et al. (2002) strongly emphasized the need for the insertion of management games to practitioners and engineering students in organizations and universities, respectively, in order for 
them to learn specific tasks and aptitudes like communication and co-operation in complex distributed production systems. Up to now, there has not been so much research carried out to understand why specific games work or do not work. This paper presents three case studies of three games to start to understand how they work.

\section{Case Studies of Serious Games}

This section describes three case studies of serious games showing how their pedagogical aims and evaluation results compare. In all three cases we have used a blended learning concept based on Kolb's experiential learning cycle (Kolb, 1984). The experience so far has shown that a well-designed game will not only help the learner to transfer theoretical knowledge to practical skills, but also to transform the gained experience into knowledge so that they can assess previously acquired knowledge and generate new understanding. The games are used by students at masters level and by engineers in industry. The authors have been using serious games for the mediation of skills to engineering students for several years and have collected good feedback both from the students as well as from the analysis of the learning outcomes (Riedel \& Baalsrud Hague, 2011). However, with some groups the gaming approach went wrong resulting in a low learning outcome and high stress factors for students. In this paper we analyse why the learning outcome is so dependent on the students' background, and look for mechanisms for improving the learning outcome for the user group with a low learning outcome. A brief description of the games used follows.

\subsection{COSIGA}

Cosiga is a New Product Development (NPD) simulation game. It was designed to tackle the problem of teaching today's engineering and management students the know-how of to design and manufacture new products, to equip them with the experience of design, and to teach them how to deal with the complexities of the new product development process (Riedel, et al. 2001). It is a team player game, played by five people playing in the same room, or in a distributed condition using the internet and telecommunications. Each person plays a role in the product development process (project manager, designer, marketing manager, purchasing manager and production manager) and works collaboratively together, to specify, design, and manufacture the final product - a type of truck. The product's manufacturability will be put to the test in the simulated factory to produce the final products.

COSIGA enables students to experience the process of new product development from the perspectives of the different disciplines involved in the design process and build their own understanding of the issues of design, manufacture, marketing, project management and purchasing; and the interactions between the disciplines. The game enables students to interact through continuous communication, to share and exchange information, initiate argumentation on problems and concepts, form relationships between pieces of discipline specific information and finally articulate 
knowledge and make decisions. During their experience with COSIGA students are not really learning about the technical aspects of designing and manufacturing a truck but learning how to increase their awareness of the many complex, often interdependent issues of the design process, through constant information sharing, rationale forming and building their capacity to act, make decisions and create new knowledge.

\subsection{Beware Game}

Beware is a multi-player online game implemented in a workshop setting. The application is used as a training medium for companies involved in supply networks covering the issue of risk management. Currently, Beware is designed with two distinct and independent levels. In the first level, the participant experiences risks within the organization. In this first level, the players have to specify, design and produce a simple product within their company. During the game, the players have to identify upcoming risks and think how to reduce or treat them by developing suitable communication and co-operation strategies as well to define the responsibility of each role. The players can communicate using the inbuilt chat, phones or Skype or also schedule physical meetings to discuss relevant issues.

In the second level, the players are faced with the design, development and manufacturing of an extended product - a cell phone with a range of services. The players use their acquired knowledge and skills in the inter-organisational contract negotiations as well as to carry out the collaborative production in a distributed environment. While the simulated service company takes the consortia's leadership and develops services, the two simulated manufacturing companies develop and produce generic cell phone parts. As the necessary information will be distributed unequally, the students have to cooperate to enable the constant flow of information that will then lead to a constant flow of material. Also there different events and risks included, and the player needs to carry out some risk management tasks.

The game enables students to identify how different types of risks impact differently on the success of the collaboration and also how the impact of risks increases and affects the partners' success over time, if no actions are taken to reduce and control the risks. The students have the possibility to apply risk assessment and risk management methods and thus increase their awareness of risks in production networks as well as the complexity of decision making.

\subsection{Set-Based Concurrent Engineering Game (SBCE)}

Set Based Concurrent Engineering is a concept in new product development based on the lean thinking perspective. It is going to be more diffused in future production systems, due of its advantage in decreasing the time and cost of production. The aim of this serious game is highlighting the benefits of applying the SBCE concept in producing a simplified airplane. It is a teamwork game that includes four members who take the role of each department (body, wing, cockpit and tail). In the first stage players will be asked to design an airplane regarding both customer requirements and supplier components 
based on a point-based approach and then they will be introduced to the SBCE enablers that they need to execute to design the airplane, with the same data given in the first stage. Finally, after playing the game, players will observe that applying SBCE decreases the time and cost of the design (Kerga, et al. 2011).

\section{Comparison of the Games' Learning Goals}

It is useful to compare the learning goals, or objectives, of the three serious games. The table below shows their learning goals.

Table 1. Learning objectives of the three games

\begin{tabular}{|c|c|c|c|}
\hline Learning goals & Cosiga & Beware & SBCE \\
\hline $\begin{array}{l}\text { To aid the players to understand the enabling factors which lead to an } \\
\text { effectual product development by applying Set-Based Concurrent } \\
\text { Engineering. }\end{array}$ & & & $\mathrm{x}$ \\
\hline $\begin{array}{l}\text { To help players to understand the new product development process and } \\
\text { apply Concurrent Engineering principles and practice. }\end{array}$ & $\mathrm{x}$ & & \\
\hline $\begin{array}{l}\text { To impart and improve knowledge of the most common Concurrent } \\
\text { Engineering rules and tools. }\end{array}$ & $x$ & & $x$ \\
\hline To acquire best practice in the Concurrent Engineering domain & $\mathrm{x}$ & & \\
\hline $\begin{array}{l}\text { To identify, analyse and solve potential problems during Concurrent } \\
\text { Engineering }\end{array}$ & $\mathrm{x}$ & & \\
\hline To develop the ability to make decisions in a complex context & $\mathrm{x}$ & $\mathrm{x}$ & \\
\hline $\begin{array}{l}\text { To support the understanding on how to apply methods supporting } \\
\text { decision making in a cooperative and competitive environment }\end{array}$ & & $\mathrm{x}$ & \\
\hline $\begin{array}{l}\text { To support the understanding of risk assessment and risk management in } \\
\text { the supply chain }\end{array}$ & & $\mathrm{x}$ & \\
\hline $\begin{array}{l}\text { To learn how to apply risk assessment and risk management methods both } \\
\text { in the supply chain as well as within a department. }\end{array}$ & & $\mathrm{x}$ & \\
\hline To identify, analyse and solve potential risks in the supply chain & & $\mathrm{x}$ & \\
\hline $\begin{array}{l}\text { To demonstrate the challenge to meet both design and customer } \\
\text { requirements. }\end{array}$ & & & $\mathrm{x}$ \\
\hline $\begin{array}{l}\text { To demonstrate how implementing Set-Based Concurrent Engineering can } \\
\text { affect the product development process }\end{array}$ & & & $\mathrm{x}$ \\
\hline To acquire and develop group communication skills & $\mathrm{x}$ & $\mathrm{x}$ & $\mathrm{x}$ \\
\hline To acquire and develop group collaboration skills & $\mathrm{x}$ & $\mathrm{x}$ & \\
\hline To acquire and improve group problem solving skills & $\mathrm{x}$ & $\mathrm{x}$ & $\mathrm{x}$ \\
\hline To acquire and improve group decision making skills. & $\mathrm{x}$ & $\mathrm{x}$ & $\mathrm{x}$ \\
\hline To acquire and improve group negotiation skills & $\mathrm{x}$ & $\mathrm{x}$ & \\
\hline $\begin{array}{l}\text { To acquire and develop the ability to develop a common understanding } \\
\text { with others in a CE Group }\end{array}$ & $\mathrm{x}$ & & \\
\hline $\begin{array}{l}\text { To acquire and develop the ability to appreciate, understand and make } \\
\text { good use of the contribution of others }\end{array}$ & $\mathrm{x}$ & & \\
\hline To improve risk management skills & & $\mathrm{x}$ & \\
\hline $\begin{array}{l}\text { To raise awareness, understanding and coping with the typical day-to- } \\
\text { day problems in working collaboratively with people from different cultures } \\
\text { and languages. }\end{array}$ & $\mathrm{x}$ & & \\
\hline $\begin{array}{l}\text { To acquire and develop the ability to collaborate in a European industrial } \\
\text { context. }\end{array}$ & $\mathrm{x}$ & & \\
\hline
\end{tabular}

From the above table we can see that there are a number of similarities between the learning objectives of the games (notwithstanding the fact that two of them are focused on NPD and concurrent engineering). The learning goals address: subject 
specific domain knowledge, individual skills and group skills: communication, problem solving, decision making, negotiation, etc. All three games were designed to help engineers and students to develop a practical understanding of a specific engineering technique - new product development, risk management and concurrent engineering. However, engineering is not just about the use of specific techniques or methods to solve problems; it is about groups of engineers working cooperatively together. Therefore, all three games place an emphasis upon developing the group skills of the participants.

\section{Comparison of the Games' Learning Outcomes}

The above table summarises the results of several evaluations carried out on the three games. A primary way to tell if a game is simulating the intended process correctly is to examine the communication flow within the game - who is asking who for information and who is supplying information. Various post-game questionnaires were used to determine if the participants had learnt the appropriate concepts. This showed that some concepts were learnt very well, but others less so - eg. the importance of product cost in Cosiga declined after the game, this was due to their being very little emphasis placed on product cost in the game itself (Riedel \& Pawar, 2009). Another influence on participants' learning was their prior knowledge and their liking of the gaming method. For the learning from the serious game to be successful the participants need to have the same level of knowledge - if some of the players have inadequate background knowledge, gaming is less successful.

Table 2. Learning outcomes of the case study games

\begin{tabular}{|c|c|c|c|c|}
\hline & \multirow{2}{*}{ Social/Soft Skill } & \multicolumn{3}{|c|}{ Knowledge } \\
\hline & & Declarative & Procedural & Strategic \\
\hline 己ٌ & $\begin{array}{l}\text { Different types of } \\
\text { communication } \\
\text { were observed (e.g. } \\
\text { ask for information, } \\
\text { offer information, } \\
\text { request action, etc) } \\
\text { and the result } \\
\text { demonstrated that } \\
\text { the game } \\
\text { represented the } \\
\text { required } \\
\text { communication } \\
\text { pattern. } \\
\text { Improving } \\
\text { multidisciplinary } \\
\text { team working and } \\
\text { decision making } \\
\text { skills. }\end{array}$ & $\begin{array}{l}\text { Understanding the } \\
\text { New Product } \\
\text { Development } \\
\text { concept. } \\
\text { Understanding the } \\
\text { distribution of } \\
\text { knowledge during } \\
\text { product } \\
\text { development. }\end{array}$ & $\begin{array}{l}\text { Understanding } \\
\text { the product } \\
\text { development } \\
\text { process. } \\
\text { Understanding } \\
\text { how to } \\
\text { collaborate, with } \\
\text { downstream and } \\
\text { upstream actors. }\end{array}$ & \\
\hline
\end{tabular}


Table 2. (Continued.)

\begin{tabular}{|c|c|c|c|c|}
\hline 茪 & $\begin{array}{l}\text { Different types of } \\
\text { communication } \\
\text { during the decision } \\
\text { making process } \\
\text { were observed. }\end{array}$ & $\begin{array}{l}\text { Understanding co- } \\
\text { operative } \\
\text { production in a } \\
\text { distributed } \\
\text { environment. } \\
\text { Identify the long } \\
\text { term impact on } \\
\text { decisions made } \\
\text { both on own and } \\
\text { partners' } \\
\text { organization. } \\
\text { Supply chain risk } \\
\text { management. }\end{array}$ & $\begin{array}{l}\text { Understanding } \\
\text { how to redesign } \\
\text { the supply chain } \\
\text { for reducing risks. } \\
\text { Understanding } \\
\text { how cost, quality, } \\
\text { time, customer } \\
\text { service indicators } \\
\text { are affected by } \\
\text { the production } \\
\text { process and the } \\
\text { identification and } \\
\text { treatment of risks. }\end{array}$ & $\begin{array}{l}\text { Applying } \\
\text { several } \\
\text { methods } \\
\text { supporting } \\
\text { risk } \\
\text { manageme } \\
\text { nt. } \\
\text { Understan } \\
\text { ding the } \\
\text { long term } \\
\text { impact of } \\
\text { decisions } \\
\text { and long } \\
\text { term risks. }\end{array}$ \\
\hline $\begin{array}{l}\text { 岳 } \\
\text { है }\end{array}$ & $\begin{array}{l}\text { Improving team } \\
\text { working and } \\
\text { communication } \\
\text { skills. } \\
\text { Enhancing the } \\
\text { decision making } \\
\text { skill. }\end{array}$ & $\begin{array}{l}\text { Understanding the } \\
\text { difference between } \\
\text { two models for } \\
\text { NPD: Point-Based } \\
\text { and Set-Based CE. } \\
\text { Comprehending the } \\
\text { enabling drivers in } \\
\text { SBCE. } \\
\text { Introducing the } \\
\text { challenges to } \\
\text { develop new } \\
\text { products in order to } \\
\text { meet dissimilar } \\
\text { stakeholders' } \\
\text { requirements. }\end{array}$ & $\begin{array}{l}\text { Understanding to } \\
\text { consider a set of } \\
\text { solutions rather } \\
\text { than just one } \\
\text { solution. } \\
\text { Learning how to } \\
\text { employ Set-Based } \\
\text { Concurrent } \\
\text { Engineering } \\
\text { enablers in order } \\
\text { to reduce the } \\
\text { development time } \\
\text { and cost. }\end{array}$ & \\
\hline
\end{tabular}

\section{Conclusion}

The three games discussed in this paper are all used in the education of engineers. The games are used by students at master level and engineers in industry. The authors have been using serious games for the mediation of skills to engineering students for several years and have collected good feedback both from the students as well as from the analysis of learning outcomes. The evaluation of the games showed in general that the players were able to apply the gained theoretical knowledge and also to strengthen their collaboration skills. However, the analysis also showed that the effectiveness of the games was dependent on the group - their level of background knowledge, if it was an inhomogeneous group or a homogenous group, as well as being dependent on their openness for playing games. 
Acknowledgements. The research reported in this paper has been partially supported by the European Union, particularly through the projects: GaLA: The European Network of Excellence on Serious Games (FP7-ICT-2009.4.2-258169) www.galanoe.eu and ELU: Enhanced Learning Unlimited (FP6-IST-027866).

\section{References}

1. Corti, K.: Games-based Learning; a serious business application. PIXELearningLimited (2006), http: / /www.pixelearning.com/docs / games_basedlearning_pixelearning.pdf

2. Kerga, E., Rossi, M., Taisch, M., Terzi, S.: Lean Product and Process Development: a Learning Kit. In: 15th IFIP WG 5.7 SIG Workshop, June 5-7, Aalto University, Espoo (2011)

3. Kolb, D.A.: Experiential learning: Experience as the source of learning and development. Prentice Hall, Upper Saddle River (1984)

4. Radcliffe, D.F., Teakle, P.: Contextual Experiences in Concurrent Engineering Learning. In: The National Teaching Workshop, Australia (1994)

5. Riedel, J.C.K.H., Baalsrud Hague, J.: Serious games and the evaluation of the learning outcomes - challenges and problems. In: Cruz-Cunha, M.M., Carvalho, V.H., Tavares, P. (eds.) Computer Games as Educational and Management Tools: Uses and Approaches, pp. 263-279. IGI Global, Hershey (2011)

6. Riedel, J., Pawar, K.: A Report On The Experiences Gained From Evaluating The Cosiga NPD Simulation Game. In: IPDMC 2009, International Product Development Management Conference, June 7-8, Twente University, The Netherlands (2009)

7. Riedel, J.C.K.H., Pawar, K.S., Barson, R.: Academic \& Industrial User Needs of a Concurrent Engineering Computer Simulation Game. Journal of Concurrent Engineering: Research \& Applications 9(3), 223-237 (2001)

8. Riis, J.O. (ed.): Simulation Games and Learning in Production Management. Chapman \& Hall, London (1995)

9. Scholz-Reiter, B., Gavirey, S., Echelmeyer, W., Hamann, T., Doberenz, R.: Developing a virtual tutorial system for online simulation games. In: Proceedings of the 30th SEFI Annual Conference, Firenze, Italy (2002)

10. Sterman, J.D.: Modeling Managerial Behavior: Misperceptions of Feedback in a Dynamic Decision Making Experiment. Management Science 35(3), 321-339 (1989)

11. Swart, J., Wild, J.: A competence based approach for knowledge sharing: building the foundation for Organisational Learning. In: Sixth International Research Conference on Quality, Innovation and Knowledge, Malaysia (2001)

12. Taisch, M., Pourabdollahian, B.: Deliverable 3.1 - SIG Field Report Engineering and Manufacturing. GALA project, Milano (2011)

13. Warren, K., Langley, P.: The effective communication of system dynamics to improve insight and learning in management education. Journal of the Operational Research Society 50, 396-404 (1999)

14. Windhoff, G.: Planspiele für die verteilte Produktion. Entwicklung und Einsatz von Trainingsmodulen für das aktive Erleben charakteristischer Arbeitssituationen in arbeitsteiligen, verteilten Produktionssystemen auf Basis der Planspielmethodik, Aachen (2001) 